\title{
IIm-i Hiyelin Cebirle Olan Münasebeti Üzerine
}

\section{Ayşe KÖKCÜ*}

\begin{abstract}
ÖZ
İlm-i hiyel kavramı üzerinden Antik Yunan'da bir soruşturma yapıldığında tekhné ve episteme kavramlarına ulaş1lır. Platon'un dönemine kadar episteme ile birlikte yol alan tekhné, episteme ile birlikte en geniş manada bilmeye verilen addır. Bir şeyi kendi avucunun içi gibi bilmeyi ve bir şey üzerinde söz sahibi olmayı ifade ederler. Bilme bir şeyi aralama, açı̆̆a çıkartma biçimidir. Aristoteles episteme ve tekhné kavramları arasında neyi nasıl açığa çıkarttıklarına göre kesin bir ayrım yapar. Tekhné imal etme değil, açığa çıkarma bakımından varlığa getirtmedir. Dolayısıyla teknik bir açığa çıkartma biçimidir. Tekhnénin akli bir nitelik olduğu ve hakikate uygun açı̆̆a çıkartma yoluyla varlığa getirme anlamı bir arada düşünüldüğünde, tekhné kavramının teknik bilgi ve becerinin yanında sanat yapma faaliyetini de içerdiği anlaşılır. Platon, teknik bilgiyi (tekhné) teorik ve tecrübe sonucu elde edilen bilgi olarak ikiye ayırır. Ona göre teknoloji varlığın kopyalanmasıdır ve bu gerçekleşirken idealardan bağımsız olarak gerçekleşemez.

İslam Ansiklopedisi'nde geçtiği şekliyle Hiyel kelimesi Arapçada; hüner, çare, yöntem, tedbir gibi hem olumlu hem de oyun, aldatma gibi olumsuz anlamlara sahip hile sözcügüünü çoğuludur. İslam biliminde sınıflandırma üzerine yazılmış ilk eserlerden olan Farabî̀nin İlimlerin Sayımı (İhsâ'ül-Ulum) adlı kitabında hile ya da hileler (hiyel) kavramı tedbir lafzıyla anılmış ve matematiksel ilimlerin uygulamaya yönelik bir kısmı olarak tarif edilmiştir. İlm-i hiyel önceleri matematiğin bir alt dalı olarak ele alınırken, 10. yüzyıldan itibaren sadece makine ve mühendislik bilgisi ile sınırlandırılmış ve matematiğin dışında ayrı bir ilim dalı olarak konumlandırılmıştır. Cebir ilmi ise Mezopotamyalılardan bu yana bilinen fakat Müslüman matematikçilerle birlikte yeni bir perspektif kazanan matematiğin en önemli alanlarından biridir.
\end{abstract}

* Dr. Öğr. Üyesi, Çankırı Karatekin Üniversitesi, Edebiyat Fakültesi, Felsefe Bölümü, Çankırı/TÜRKIYYE E-posta: aysekokcu@karatekin.edu.tr, ORCID: 0000-0001-9196-6414, DOI: 10.32704/erdem.656941 Makale Gönderim Tarihi: 13.06.2019* Makale Kabul Tarihi: 25.11.2019* (Araştırma Makalesi) 
Müslüman matematikçilerin cebrin gelişimindeki önemli iki adımından birincisi; Hint sayı sistemini kullanmış olmaları, diğeri ise sayı tanımının kapsamını genişleterek irrasyonel sayıların cebir ve mukabele vasıtasıyla rasyonel sayılar gibi muamele görmelerini sağlamalarıdır.

$\mathrm{Bu}$ makalede öncelikle ilm-i hiyelin ve cebrin tarihsel arka planlar1 verilip, ardından ilm-i hiyelin cebir ilmi ile olan ilişkisi irrasyonel sayı problemi üzerinden ortaya konulmaya çalişılacaktır.

Anahtar Kelimeler: İslam bilim tarihi, İslam matematiği, ilm-i hiyel, cebir ve mukabele, Farabî. 


\title{
The Relationship Between Ilm-i Hiyel and Algebra
}

\begin{abstract}
When an investigation is made in Ancient Greece over the concept of ilm-i hiyel, the terms of tekhné and episteme are obtained. Tekhné, which traveled with the episteme until Plato's time, means knowing something like episteme in the broadest sense. They mean to know something like the back of their hand and to have a say on something. Knowing is a way of revealing something. Aristotle makes a definite distinction between episteme and tekhné concepts according to what they reveal and how. Tekhné is not to manufacture, but to bring it into existence by revealing something. Thus, the tekhné is a form of disclosure. When we consider that Tekhné is a mental quality and means bringing into existence by revealing something, we understand that the concept of tekhné includes the activity of making art as well as technical knowledge and skill. Plato divides technical knowledge (tekhné) into theoretical and experimental knowledge. According to him, technology is the replication of the entity, and it cannot be realized independently of the ideal.
\end{abstract}

In the Encyclopedia of Islam the word hiyel is the plural form of trick (hile), which has not only positive meanings like talent, solution and method but also negative meanings like trick and deceptionin Arabic. Trick or the term trick is mentioned as the word precaution and described as practical part of mathematical sciences in İhsân'ül-Ulum which was written by Farabî, one of the first Works on classification in Islamic World. While ilm-i hiyel (technology) was initially considered as a sub-branch of mathematics, it was limited to the knowledge of machinery and engineering from the 10th century onwards as was positioned as a separate brunch of science outside mathematics. The science of algebra is one of the most important fields of mathematics that has been known science Mesopotamians but has had a new perspective with Muslim mathematicians. One of the two important steps of Muslim mathematicians in the development of algebra; they used Indian number system and they expanded the scope of the definition of the numbers, allowing irrational numbers to be treated as rational numbers through algebra and reduction (mukabele).

In this article, firstly historical backgrounds of ilm-i hiyel and algebra will be given, and then the reliationship between ilm-i hiyel and algebra will be tried to be revealed through irrational number problem.

Keywords: History of Islamic science, Islamic mathematics, ilm-i hiyel (technology), algebra and reduction (mukabele), Farabî. 


\section{1. İlm-i Hiyel}

\subsection{Antik Yunan'da İlm-i Hiyel veya Tekhné Kavramı}

7 ekhné kavramının Antik Yunan'da ortaya çıkı̧̧ı M.Ö. 800’lere kadar 1 gitmektedir. Homeros'un destanlarından Hesiodos'un eserlerine kadar pek çok yapıtta karşımıza çıkmaktadır (İnam 2014: 77). İlm-i hiyel kavramı üzerinden Antik Yunan'da bir soruşturma yapıldığında tekhné ve episteme kavramlarına ulaş1lır. Platon'un dönemine kadar episteme ile birlikte yol alan tekhné, episteme ile birlikte en geniş manada bilmeye verilen addır. Bir şeyi kendi avucunun içi gibi bilmeyi ve bir şey üzerinde söz sahibi olmayı ifade ederler. Bilme bir şeyi aralama, açığa çıkartma biçimidir. Aristoteles episteme ve tekhné kavramları arasında neyi nasıl açığa çıkarttıklarına göre kesin bir ayrım yapar. Tekhné imal etme değil, açığa çıkarma bakımından varlı̆̆a getirtmedir. Dolayısıyla teknik bir açığa çıkartma biçimidir denilebilir (Heidegger 2015: 21). Yine Aristoteles'in Nikomakbos'a Etik'in altınc1 kitabında yaptı̆̆1 tanıma göre; "tekhné yapmayla ilgili akli bir niteliktir ki o aklı hakikate uygun kullanır” (Aydoğan 2017: 59). Tekhnénin akli bir nitelik olduğu ve hakikate uygun açığa çıkartma yoluyla varlığa getirme anlamı bir arada düşünüldüğünde, tekhné kavramının teknik bilgi ve becerinin yanında sanat yapma faaliyetini de içerdiği anlaşılır.

Sofistler açısından tekhné, retorik süreci ve dolayısıyla ikna kabiliyetini ifade eder. Sofistler tekhné söyleminin ortası logos (anlatılmaya çalışılan kavramlar) olan, inanç ve estetik gibi iki amaca sahip bir teknik olduğu fikrindedirler. Yani tekhné, kişilerin bilgiden çok bilgiyi sunma yöntemidir. Bir bakıma zihindeki düşüncelerin bulunulan ortamın rengine, dokusuna uygun bir formda vücuda getirilmesi işlemidir. Bu açıdan ele alındığında Farabî̀nin bahsettiği hiyel (tedbir) ile tekhnénin birbirine yakın ancak biçimsel olarak farklı kavramlar olduğu görülüyor. Retoriğin dı̧̧ında daha genel manada sokratik kaynaklara göre tekhnénin tarifi; belirlenmiş yöntemler bilgisi türünde organize edilmiş bilgi şeklindedir (Ural 2015: 139). Sofistlere göre bilgi tanımı tekhné (belli teknikler) sayesinde elde edilen doxa seviyesindeki bilgilerdir. Doxa seviyesinde bilgiden kastedilen yalnızca dünyevi melekeler vasıtasıyla elde edilen sınırlı bilgidir (Akalın 2017: 6). Platon'a göre doxa sözde bilgiye karşılık gelen sanı anlamından ötürü cehalet ve bilme arasında bir yerdedir. Dolayısıyla Platon ve diğerleri için bu bilgi bütün dünyanın varoluş amacını açıklayabilecek seviyede bir bilgi olarak kabul edilemez. Doxa ideaların kendisi değil görüntüsüdür. Duyular vasıtasıyla elde edilen, değişen fiziksel dün- 
yanın bilgisidir ve değişen bir şeyin mutlak bilgisinden söz edilemez (Cevizci 2014: 229).

Platon, teknik bilgiyi (tekhné) teorik ve tecrübe sonucu elde edilen bilgi olarak ikiye ayırır. Ona göre teknoloji varlığın kopyalanmasıdır ve bu gerçekleşirken idealardan bağımsız olarak gerçekleşemez (Plato 2016: x 899a ff; Platon 2015: 62). Platon'un; kozmolojisini, evrenin nasıl oluştuğu konusundaki fikrini ve doğa anlayışını ifade ettiği Timeios diyalogunda verdiği zanaatkâr örneği tekhné kavramının varlığın kopyalanması olduğu konusunda bize bir açıklama verebilir. Platon'a göre bir zanaatkâra elindeki altın ile yaptı̆̆ 1 nesnelerin hakikati sorulduğunda, onların hakikatinin şekillerinden bağımsız olarak altın olduğunu söylemelidir. Nesnelerin sonradan sahip oldukları üçgen vs. gibi şekiller yapımları esnasında bile değişmektedir. Bu sebepten bunlardan gerçek nesnelermiş gibi bahsetmemiz abes olur. Bütün nesneleri kapsayan öz, hiçbir zaman kendi özünden bir şey kaybetmediği için her zaman aynı ismi taşımalıdır. Özünde her şeyi kapsamak olduğu için kapsadığı şekillerden hiçbirine benzer bir şekil almaz. Ancak onun içine geçen şeyler harekete geçer ve şekil alır. Her seferinde farklı biçimde görünmesinin sebebi de budur. Sonuç olarak özün içine giren ve çıkan nesneler başlangıcı olmayan varlığın kopyalarıdır (Platon 2015: 62).

\section{2. İslam Dünyasında İlm-i Hiyel Üzerine Yazılan Eserler}

İlm-i hiyelin İslam bilim tarihindeki karşılığı; teknoloji ve beraberinde mühendislik alanını da kapsayacak mekanik bilgidir. Müslümanların ilm-i hiyel konusundaki bilgileri diğer matematiksel bilimlerde olduğu gibi öncelikle kendilerinden önceki milletlerden (Antik Yunan, Hint, İran, Misır, Mezopotamya vb.) çeviriler yoluyla tevarüs ettikleri eserlere dayanır. Bu konuda Müslümanların en çok faydalandığı eserlerin başında Bizanslı Philon’a (ö. MÖ 220) ait olan Pneumatica adlı eser gelir. Bir diğeri, çevirisi Kusta b. Luka (ö. 912-13) tarafindan yapılan İskenderiyeli Heron'a (10-70) ait Kitâb ref'ileskâl (Mekanik) adlı kitaptır. Sonuncusu ise Archimedes'e (ö. MÖ 202 civ.) ait olduğu düşünülen su saatleri ile ilgili bir risaledir. İslam medeniyetinde ilm-i hiyel konusunda yazılmış ilk telif eser, 9. yüzyılda yaşamı̧̧ Benu Musa kardeşlerden (Muhammed, Ahmed ve Hasan) Ahmed'in Kitâb el-Hiyelidir (Dosay ve Demir 2019: 4).

Ahmed b. Musa, Kitâb el-Hiyelde yüzden fazla makinenin çalışma prensiplerine yer verir. Latince nefes anlamına gelen pneuma sözcüğünden türeyen 
pnömatik ifadesi Ahmed b. Musa'nın Kitâb el-Hiyelde anlattığı makinelerin çalışma prensipleriyle doğrudan bağlantılıdır. Kitapta anlatılan makineler; basınçlı havanın kullanımını temele alan pnömatik ile hidrolik bilgisi sayesinde elde edilen itiş gücü ve makaralar, dişliler gibi basit makineler yard1mıla çalışan otomat sistemlerdir. Söz konusu makinelerin seksen tanesini gemi kaldırma mekanizmaları, diğerlerini ise çeşmeler, lambalar ve kirli kuyularda kullanılmak üzere tasarlanmış bir gaz maskesi ve bir de kıskaç kepçe oluşturur (D. R. Hill 1991: 172). İslam bilim tarihinde Ahmed b. Musa'nın eserini takip eden bir diğer eser, 11. yüzyılda Endülüs'te yaşamış İbn Halef el-Murâdi'nin Kitabu'l-esrârfî̀netaici'l-efkâr' 'dır. Eser, dişli çarklardan oluşan otomatlar üzerinedir. Hidrolik prensiplerin kullanıldığı su saatleri ile ilgili çalı̧̧ma ise adını saatler üzerine yaptığ ${ }_{1}$ çalışmalardan alan Rıdvan b. Muhammed el-Saâti'nin (ö. 1231) 1203 yılında yazdığ İlmu's-saat ve'l-amel bihâ adlı eseridir (Fazlığlu ve Koç 2000: XXVII).

İlm-i hiyel tarihinin Anadolu'daki temsilcisi Cizreli meşhur mühendis Bedî‘uz-Zamân Ebu'l-'İzz İsmâ‘̂̂l b. er-Rezzâz el-Cezerî'dir (1205-06'da sağ). Cezerî kendinden öncekilerin hiyel konusundaki bilgi birikimini de kullanarak inşa ettiği otomat sistemleriyle onların bir adım ilerisine geçmeyi başarmıştır. Artuklular döneminde yaşayan Cezerînnin önce tasarlad1ğ1 ve sonrasında inşa ettiği eserlerden hiyel hakkında yazmış olduğu kitap vasitasiyla haberdar oluyoruz. El-Câmi“ Beyne'l-İlm ve'l-Amel En-Nâfi fî̀ Es-Sınaấti'l-Hiyel adlı eseri bir mukaddime ve altı bölümden oluşur. Kitabı yazma sebebini mukaddimesinde Artuklu Sultanı Ebu'l-Feth Mahmut İbn-i Mehmet İbn-i Karaaslan’a yaptığı makinelerden birini göstermesi üzerine sultanın onu yüreklendirerek bu makinelerin nasıl yapıldığını açılayan bir eser kaleme alması gerektiğini söylemesi olduğunu anlatır (Fazlıŏlu ve Koç 2000: 8). Cezerî eserinde uygulamaya aktarılmayan bir bilginin güvenilirliğinin sağlanamayacağını dile getirerek amelî ilmin (uygulamalı bilim) nazari ilme göre doğruluğunun daha kanıtlanabilir olduğunu vurgular.

Cezerî̀den sonra ilm-i hiyel konusunda Takiyüddîn Râsıd'ın (ö. 1585) bahsettiği ancak günümüze ulaşmadığı için içeriği noktasında fazla bilgiye sahip olmadığımız Ali Kuşcu'ya (ö. 1474) ait et-Tezkire adlı bir eser bulunmaktadır. Bunun yanında Takiyüddin Râsıd'ın kaleme aldığı bir diğer hiyel eseri de El-Turuk el-Seniyye fi el-Âlât el-Ruhâniyye adlı eserdir. Söz konusu eser 1976 yılında Ahmed Yûsuf el-Hasan tarafindan Halep’te basılmıştır (Fazlıoğlu ve Koç 2000: XXIX). 


\section{3. İlm-i Hiyel'in Diğer İlimler İçerisindeki Konumu}

Farabî̀nin ifadesine göre tedbir ilmi (ilm-i hiyel): varllğı burhanlarla kanıtlanmış olan her şeyin tabii cisimlere uygulanması ve onlarda fiilen gerçekleştirilmesi için alınması gereken tedbirlerin ilmidir (Farabî 2019: 37). İlm-i hiyelin bugünkü anlamı olan teknoloji sözcüğü, Farabîye göre teorik matematiğin (buradaki anlamı daha çok geometri) zihinsel olarak ispatladığı gerçeklerin tabiatta cisimleşebilmesi için alınması gereken tedbirleri ifade eder (Farabî 2019: 37). Farabîye göre matematik ilimlerinin en üstünü olan ilm-i hendese (geometri); nazari ve amelî olmak üzere iki kısma ayrılır (Farabî 2019: 28). Amelî hendese (uygulamalı geometri) daha çok teknik anlamda geometri bilgisi vasıtasıyla gerçekleştirilen mühendislik, mimarlık ya da marangozluk gibi zanaat ehlinin kullandığı bir ilimdir. Amelî hendesenin nesneleri maddi cisimlerdir ve fiziksel dünyaya ait duyularla idrak olunan bu cisimlerle ilm-i hiyel vasıtasıyla zihinde tasavvur edilen üçgenler, doğrular, yüzeyler arasında bir ilişki kurulur.

Farabînnin bahsettiği söz konusu tedbirleri alabilmek ya da ilm-i hiyeli uygulayabilmek için öncelikle tabiatın çok iyi tahlil edilmesi ve tanınması gereklidir. Bunun anlamı, varlığın içsel ve dişsal olarak hangi özelliklere sahip olduğu ve bu özelliklerin yanı sıra varlıkların aralarındaki ilişki hakkında bilgi sahibi olunması gerektiğidir. Böylece ilm-i hiyel sayesinde fizik kurallarına tabi olan kâinat ile matematiksel açıdan kanıtlanmış önermelerin uyumlu bir şekilde bir araya getirilmesi temeline göre çalı̧san aletlerin ya da makinelerin yapımı gerçekleştirilebilir. Bu doğrultuda düşünüldüğünde teknoloji ile ilişkilendirilen hiyelin kapsamı; mühendislik, mimarlık, zanaat ve sanat alanında kullanılan teknik bilgi olarak düşünülebilir. Hiyel vasıtasıyla başka bir forma dönüştürülen varlığın doğası gereği çıkaracağı problemlerin çözümü için bir hileye (yola) başvurulur ve sonuçta problem çözüme kavuşur. Anlaşılacağ1 üzere hiyel, çıkabilecek sorunların aşımında yardımcı olacak bir araç mahiyetindedir.

Farabîden sonra gelen ilim tasnifi konusunda eser yazanların ilm-i hiyeli matematiğin bir alt dalı olmaktan çok, ayrı bir ilim dalı olarak ele aldığını görüyoruz. İslam dünyasında Farabî̀den sonra ilimlerin sınıflandırmaları konusunda kendinden sonrakileri en çok etkileyen metinlerden biri olan ve kâtiplerin devlet işlerinde kullanacakları teknik terimleri açıklamak amacıyla Harezmli bir bürokrat olan Muhammed b. Ahmedb. Yusuf el-Hârezmi (ö. 997) tarafindan yazılan Mefâtibu'l-Ulûm'da bu yaklaşımın ilk hali dikkat çekmektedir. 
Mefâtihu'l-Ulûm'da yapılan sınıflandırmanın içerisinde ilm-i hiyel herhangi bir ilim grubuna dâhil edilmemiş yabancıların ilmi(gayr-1 arabî, 'ulûmu'l-'acem) olarak adlandırılan; felsefe, mantık, tıp, aritmetik, hendese, yıldızlar ilmi, musiki ve kimya ilimlerinin arasında müstakil bir biçimde yer verilmiştir (el-Hârezmi 2019: 170-316). Hârezmi ilm-i hiyeli sadece makine ve mühendislik bilgisi ile sınırlandırır. Ona göre hiyel ilminin kısımlarından biri az bir kuvvetle ağırlıkları çekmektir (cerr-i eskâl) ve bunun için kullanılması gereken aletler; bertis, muhil, beyram, kesiratu'r-raf, isfin, bugu, zeytin sıkıcı (galagara), hâzir, ok, ciz' ve estâmdır. İlm-i hiyelin ikinci kısmında su basıncının kullanıldığı aletlerin tanıtımı yapilır (Hârezmi 2019: 300-308).

Bu sinırlandırma ile ilm-i hiyel, teorik matematiğin ve uygulamalı matematiğin bir alt dalı olmaktan çıkar ve ayrı bir ilim olarak ele alınır. 14. yüzyıla gelindiğinde ilm-i hiyelin İbnu'l Ekfâni’nin (ö. 1348) ilimlerin tasnifini verdiği İrşâdu'l-kâsıd ilâ esne'l-makâsıd adlı eserinde hendesenin içerisinde olduğunu görüyoruz. Ekfâni'nin ilm-i hiyel olarak sınıflandırdığg ilimler; ilm-i ukûdi'l-ebniye (bina yapım bilgisi), ilm'ul-meraya'l-muhrika (yakıcı aynalar ilmi), ilm-i merâkizi'l-eskal (ağırlık merkezi hesabı), ilmü'l-misaha (alan ve hacim hesabı), ilm-i inbâti'l-miyah (yer altı sularının tespiti), ilm-i cerri'leskal (ağırlık kaldırma), ilmu'l-benkâmât, ilmü'l alâti'l- harbiye ve ilmü'l alâti'l-ruhaniyye (savaş ve diğer alet, edevat, makine yapım bilgisi) şeklinde sınıflandırılmıştır (Fazlığlu ve Koç 2000: XXV). Bu sınıflandırma içerisinde sayılan ilimlerin hepsi el-Hârezmi'de olduğu gibi daha çok makine ve mühendislik bilgisidir, ayrıca mimarlar için gerekli inşaat bilgisi de ilm-i hiyele dâhil edilmiştir.

\section{Cebir İlminin Tarihi Arka Planı}

Cebrin birinci ve ikinci dereceden problemlerin çözümünde kullanılması Mezopotamyalılar tarafından yüzyıllar önce gerçekleştirilmiştir. Mezopotamyalılar bilinmeyen değerin bulunması için geometri yerine analitik yöntemleri tercih ederek geometrik çözümü göz ardı etmişlerdir. Komşuları olan Misırlılar ise matematik problemlerini geometri vasıtasılla çözmeyi tercih ediyorlard. Bu coğrafyaya uzak bir noktada doğan ve gelişen Hint matematiğinin karakteri ise daha çok sahip olduğu sayı sistemi ile ilgilidir. İçerisinde sıfirın da olduğu konumlu onluk sayı sistemi sayesinde hesap konusunda oldukça mahir oldukları anlaşılan Hintli matematikçilerin Müslüman matematikçilere etkisi büyüktür. 
Cebir kelimesi ilk kez bir kitabın başlı̆̆ında büyük astronom ve matematikçi Hârezmi (ö. 850) tarafından 825 y1lında yazılan El-Kitab'ul Mubtasar fi'l Hesab'il Cebr ve'l Mukabele isimli eserde kullanılmıştır (Cajori 2014: 125). Mezopotamya kökenli cebir kelimesinin sözlüklerde pek çok karşılı̆̆ı bulunmaktadır (Sayılı 2015: 4). Arapça cebere fiilinde karşımıza çıkan en yaygın iki kullanımından biri; kırık kemiği yerine koyma iken bir diğeri, zorlama ve mecbur etmedir. Hârezmi’nin cebir anlayışı, cebir kitabının başlığında kullandığı iki kelimeye dayanır; cebir ve mukabeleye, başka bir ifade ile iyileştirme ve eşitliğe.

Hârezmi'nin cebri tamamen retoriktir, denklemlerde simgeleri değil sözcükleri kullanır. Cebir, bir eşitliğin her iki tarafına eşit büyüklükleri eklemek suretiyle yapılan iyileştirmedir. Eşitliğin herhangi bir tarafında bulunan negatif sayının ortadan kaldırılması için her iki tarafa da negatif sayının pozitifinin eklenmesidir de denilebilir. Mukabelenin anlamı ise eşitliğin her iki tarafında bulunan pozitif sayıların yok edilebilmesi için aynı sayıyı her iki taraftan çıkarmaktır. Başka bir deyişle her iki tarafa o sayının negatifini eklemektir. Bu dönemin cebrinin kullandığ1 diğer iki matematiksel kavram; red (geri çevirme) ve ikmaldir (tamamlama). Reddin işlemsel anlamı denklemde $f(x)$ 'in sabit katsayısından kurtulmak amaciyla denklemin her iki tarafının $\mathrm{f}(\mathrm{x})$ 'in katsayısına bölünmesidir. İkmale gelince o da yine $\mathrm{f}(\mathrm{x}$ )'in paydası konumundaki sabit katsayıdan kurtulmak amacıyla eşitliğin her iki tarafinın aynı katsayı ile çarpılmasıdır (Dosay 1991: 10). Cebir, mukabele, red ve ikmalle eşitliğin her iki tarafına dört işlemi uygulamak suretiyle $\mathrm{f}(\mathrm{x}$ )'in yalnız bırakılması hedeflenmektedir.

İkinci derece denklemlerin dokuz tipi için cebirsel çözüm üreten Mezopotamyalılar, karşılarına çıkan problemi öncelikle bu dokuz tipten birine uygun hale dönüştürüyorlar ve belli çözüm formülleri uygulayarak problemi çözüyorlardı (Sayılı 1996: 41). İkinci dereceden yüksek dereceli denklemlerin ise ancak ikinci dereceye indirgenebilenleri çözülebiliyordu. Bu denklem tipleri ile 9. yüzyılda Hârezmi ve İbn Türk'ün (847'de sağ olduğu düşünülmekte) eserlerinde de karşılaşılmaktadır. Söz konusu matematikçilerin Mezopotamyalılardan farkı; problemleri bu denklem tiplerine çevirmelerinin ardından ispata tam kareye tamamlama metodunu kullanarak ulaşmalarıydı (Sayılı 1996: 43). İslam matematiğinin ilk örneklerinde cebir, analitik yöntemlerden ziyade geometrik bir karaktere sahiptir. Geometrik yöntem sayesinde Mezopotamyalıların yadırgadığı ikinci derece bir denklem için iki çözümün olması 
sorunu da aşılmış olur. Aslında mesele geometrik yöntemin kullanılmasıyla göründüğünden daha kolay bir şekilde halledilir.

Bu açıdan bakıldığında İslam matematikçilerinin cebir anlayışı Mezopotamyalılarınkine nazaran daha sade ve anlaş1ırdır. Matematiğin bir dalı olan cebir, İslam matematiğinde genellikle hesabın, yani aritmetiğin ve geometrinin cebre uygulanması ile iki ayrı alanda gelişimini sürdürdü.

Cebrin diğer ilimlerde olduğu gibi günlük hayattan kaynaklanan problemlerle yakın ilişkisi bulunmaktadır. İslam cebir geleneğinin ilk eserlerinin yazılış nedeni; miras hukuku, arazi paylaşımı ve ticari problemlere çözüm arayışlar1 gibi gündelik problemlere aranılan matematiksel çözümüdür. Geometrik çözüm ve ispat yolunu kullanan İslam cebrinde $\mathrm{x}$ bilinmeyen uzunluğu, x.x. veya $\mathrm{x}^{2}$; kenar uzunluğu $\mathrm{x}$ olan bir karenin alanını ve $\mathrm{x} . \mathrm{y}$ ise bir kenarı $\mathrm{x}$, diğer kenarı y olan bir dikdörtgenin alanını gösterir (Dosay 1991: 13).

İslam cebrinin gelişmesinde önemli adımların sahibi olan Ebu Kâmil'in (850-930) cebri, Hârezmi gibi tamamen retorikti ve cebirsel ispatlarında geometrik çözüm yöntemini benimseyerek tam kareye tamamlama yöntemini kullanıyordu. Bu açıdan bakıldığında Ebu Kâmil'in eski İslam cebir geleneğinin son temsilcisi olduğunu söyleyebiliriz. Bunun yanı sıra Ebu Kâmil'in cebre getirdiği yenilikler arasında en önemli olanı; irrasyonel sayıları katışık denklemlerin sadece kökleri olarak değil, katsayılarında da kullanmış olmasıdır. Ebu Kâmil'den önce bilinmeyenin karesi $x^{2}$, kenarı x olan bir karenin alanını ifade etmekteydi. Ebu Kâmil $x^{2}$ yi geometrik bir kare anlamından çıkarmış ve $\mathrm{x}$ gibi $\mathrm{x}^{2}$ 'nin de bir uzunluk olarak düşünülebileceğini ifade etmiştir (Dosay 1991: 24). Ebu Kâmil’e göre x geometrik bir büyüklükle temsil edilen bir sayıdır. Dolayısıyla $\mathrm{x}$ ile $\mathrm{x}$ in ya da $\mathrm{x}$ ile y'nin çarpımı da yine bir sayıdır (Corry 2017: 149). Ayrıca Ebu Kâmil, Hârezmi'nin eserinde yer verdiği muamelat (miras, borç gibi konularda yapılan hesap), mesaha (yer ölçümü) ve vesâya problemlerini kitabına dâhil etmemiş, bu konuları içeren ayrı bir kitap yazarak cebri ayrı ve bağımsız bir alan olarak ele almıştır (Aydın 1994: 173). $\mathrm{Bu}$ ayrilışla beraber Ebu Kâmil ve sonrasında cebir; geometrik problemlerin çözümünde güçlü bir araç olmanın yanı sıra aynı teknikler vasıtasıyla kendi içerisinde de gelişimini sürdürmüştür. Bu anlayışın yansımalarını ilimlerin tasnifi konusunda yazılmış eserlerde de görmek mümkündür. Farabînnin ilm-i hiyel el-adediyye içerisinde kullanılan bir alan olarak yer verdiği cebre, el-Hârezmi, Mefâtibu'l-Ulûm'unda cebir ilmine ikinci makalenin dördüncü babı olan aritmetiğin beşinci faslında "Hesapların Yönleri Hakkında" başl1ğında ayrı bir matematik alanı olarak yer verir (el-Hârezmi 2019: 244). 


\section{3. İlm-i Hiyel ve Cebir İlişkisi}

İlm-i hiyel matematiğin bir alt dalıdır. İlm-i hiyel kısaca: Fiziki dünyanın tabiatı gereği sahip olduğu kurallar ve ilkelerle matematiğin zihinsel nesneleri ve ispat yollarının bir arada uyumla işleme sokulmasını sağlayan bir yöntemdir. Farabî̀nin matematiksel bilimlerin içerisine konumlandırdığ 1 ilm-i hiyelin diğer bilimlerle olan münasebetini aşağıdaki şema ile daha net bir şekilde görmek mümkündür (Farabî 2019: 27-38).

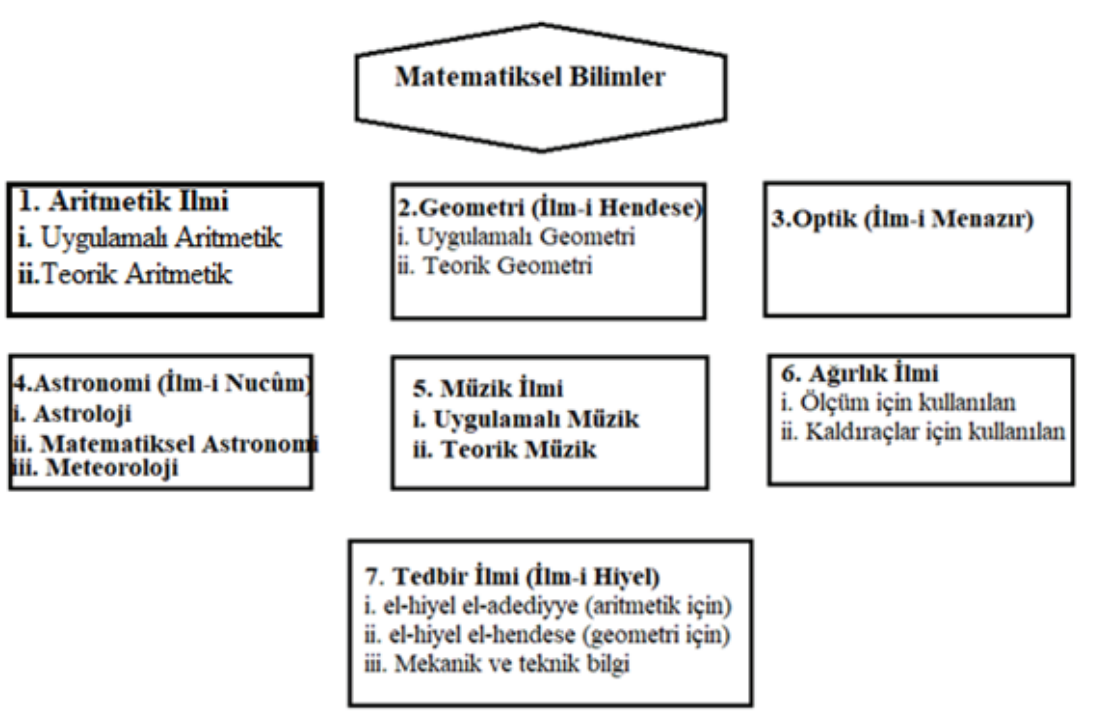

Cebir, şemada 7. bölüm olarak gösterilen ilm-i hiyelin i. maddesinde bulunan el-hiyel el-adediyye yani aritmetik ilmi için gerekli olan hiyel bilgisine örnek olarak verilir. Farabî el-hiyel el-adediyye içinde konumlandırdığg "cebir ve mukabelenin” sadece aritmetiği değil, geometriyi de ilgilendiren bir ilim olduğunu vurgular. Bu yorumun temelinde Antik Yunan matematiğinde rasyonel ve irrasyonel sayıların teşkil ettiği karışıklık bulunmaktadır.

Öncelikle Farabîde de (diğer Müslüman âlimlerde olduğu gibi) geometrinin diğer bilimleri kapsayan bir yapıda olduğu düşüncesi bulunur. Bu düşüncenin birinci nedeni geometrinin kullandığı yöntemdir. Geometri, Öklid'in Elementler'inde gösterildiği üzere diğer ilimlerden farklı bir yönteme sahiptir. Geometri eldeki sınırlı ön kabullerle (aksiyomlar) sınırsız çıkarımlarda bulunabilir. İkincisi ise geometrinin Allah'ın bir eseri olan kâinatı anlamada bir 
araç olarak görülmesidir. Allah kâinatı belli bir ölçü üzere yaratmıştır ve bu ölçü, ilimler arasında en çok geometri ile ilişkilidir. Her ölçü temelde geometrik bir bilgidir ve geometri ölçüden ibarettir denilebilir (Guenon 2012: 46).

$\mathrm{Bu}$ yaklaşım doğrultusunda Pisagorcuların karşılaştıkları irrasyonel (oransal olmayan) sayıların ölçülememesi, her şey sayıdır mottosuna sahip bir matematik topluluğunun sayının tanımında belirsizliğe düşmesi anlamına geliyordu. Pisagorcular, geometrik şekillerin kenar uzunlukları arasında bir ilişki olduğunu biliyorlardı. Bu ilişkiyi gösteren en temel teorem Pisagor'un adıyla bilinen; bir dik üçgenin iki dik kenarının kareleri toplamının hipotenüsünün karesine eşit olduğunu söyleyen teoremdir. Bir karenin kenar ve köşegeni arasinda bu teorem vasitasiyla bilinen bir oran bulunur: $\frac{1}{\sqrt{2}}$. Paydada yer alan $\sqrt{2}$ irrasyonel sayısı, Pisagorcu aritmetiğin dayandığı orantı kavramının dı̧̧ında bir orantısızlık durumuna yol açar. Pisagorcular için orant1; a, b, c ve d birer tam sayı olmak üzere $\frac{a}{b}=\frac{c}{d}$ eşitliğinin gerçekleşmesidir. Sayısı söz konusu orantıyı sağlamaz ve 1 ile 2 tam sayısının arasında bir büyüklüğe karşılık gelmekle beraber, tam olarak ölçülemez. Yunanlar orantı kavramını geometrik uzunluklar üzerine uyguladıklarında verilen herhangi bir uzunluğun kendisinden küçük bir birim kullanmak suretiyle ölçülebileceği kanısındaydılar (Corry 2017: 54-61). Söz konusu yöntem irrasyonel bir büyüklüğün ölçümü için yetersizdi.

Bu kadim problemin halledilmesi için aritmetiğin daha önce düşünülmemiş ve uygulanmamış bir teknolojiye (yönteme) ihtiyacı vardı. Bu yeni teknolojiyi (ilm-i hiyeli) matematiğe sağlayan cebir ve mukabele idi. Farabînin ifadesiyle cebir ve mukabele: "Euclides'in Elementler adlı kitabının onuncu bölümünde ilkelerini verdiği irrasyonel ve rasyonel (asam ve muntak) sayılarla bu bölümde zikretmediği diğerlerinde kullanılmaya yarayan sayıların çıkarsanması için alınması gereken tedbirleri içine alır." (Farabî 2019: 37-38). Yine Farabînin açıklamasına göre bunun nedeni irrasyonel ve rasyonel sayıların birbirlerine oranlarının, sayların birbirlerine oranları gibi olmasından kaynaklanır ve sonuçta ister irrasyonel ister rasyonel olsun bütün sayılar herhangi bir büyüklüğe sahiptir.

Antik Yunanların ölçülemez olarak kabul ettikleri irrasyonel sayılar İslam cebrinde, rasyonel sayılar gibi muamele görüyordu. Bunun anlamı sayı kavramının farklı bir yaklaşımla ele alınıyor olmasıydı. Hârezmi eserinin başında öncelikle tam sayıları Aristoteles'in yaklaşımıyla birliklerden kurulu çokluk olarak ifade eder. Sonrasında gözlemlerine göre cebir ve mukabele ile hesap- 
lanması gereken matematiksel ifadelerin; kökler (cüzler), kareler (mâl) ve ne kökle ne de karelerle ilişkisi olmayan basit sayılar olduğunu söyler (Rosen 1831: 5). Hârezmi’nin cebrinde sayılar bu üç sınıfı esnek bir biçimde kapsar. Örneğin durûb-1 sitte olarak bilinen denklemlerinin retorik versiyonları şöyledir:

$$
\begin{aligned}
& \text { kareler katsayıya eşittir } \quad\left(a^{2}=b x\right) \\
& \text { kareler sayılara eşittir } \quad\left(\mathrm{ax}^{2}=\mathrm{c}\right) \\
& \text { katsayılar bir sayıya eşittir } \quad(b x=c) \\
& \text { kareler ve katsayılar bir sayıya eşittir }\left(a^{2}+b x=c\right) \\
& \text { kareler ve sayılar bir katsayıya eşittir }\left(a^{2}+c=b x\right) \\
& \text { katsayı ve sayılar bir kareye eşittir } \quad\left(b x+c=a x^{2}\right)
\end{aligned}
$$

Hârezmi çözdüğü altı tip ikinci dereceden denklemi ifade ederken "Bir sayının karesi ve herhangi bir katı bir sayıya eşittir." çerçevesinde ele alır. Hârezmi'nin bu yaklaşımında sayı kavramının kapsamı ve tanımı daha esnek bir yapıda sunularak; pozitif ve negatif sayılar, kesirler ve kökler sayı düşüncesinin kapsamına alınır (Corry 2017: 129). Bu sayede Antik Yunanların oran teorisine uymadığı için sayı olarak kabul etmedikleri irrasyonel sayıların da diğer sayılar gibi bir büyüklük olduğu konusu cebir ve mukabele ile beraber çözüme kavuşturulmuş olur. 


\section{SONUÇ}

İslam Ansiklopedisi'nde geçtiği şekliyle Hiyel kelimesi Arapçada; hüner, çare, yöntem, tedbir gibi hem olumlu hem de oyun, aldatma gibi olumsuz anlamlara sahip olan hile sözcüğünün çoğuludur. İlm-i hiyel ve cebir münasebetinin kurulabilmesi için öncelikle ilm-i hiyelin teknik bilgi, teknoloji ya da çözülemeyen bir problemin çözümü için alınması gerekli tedbirlerin bilgisi anlamları üzerinde durmakta fayda vardır.

Farabînnin bahsettiği hiyel (tedbir) ile Antik Yunanlardaki tekhné kavram1nın birbirine yakın ancak biçimsel olarak farklı kavramlar olduğu aşikârdır. Farabîye göre hiyel vasıtasıyla başka bir forma dönüştürülen varlığın doğas1 gereği çıkaracağı problemlerin çözümü için bir hileye (yola) başvurulur. Anlaşılacağı üzere hiyel, çıkabilecek sorunların aşımında yardımcı olacak bir araç mahiyetindedir. Antik Yunanların matematik alanında Pisagor'la başlayan süreçle çözüme kavuşturamadıkları ya da başka bir ifadeyle natamam b1raktıkları en önemli problemlerden biri irrasyonel sayılar konusudur. 9. yüzyılda Hârezmi ve İbn Türk ile başlatılan yeni cebir geleneği sayesinde farklı bir yaklaşımla ele alınan bu konu; özellikle Hârezmi'nin cebir eserinde sayı kavramı tanımının ve çerçevesinin değişimiyle farklı bir bakış açısı kazanmıştır. Artık sayı kavramı; içerisine pozitif, negatif, kesirli ve köklü sayıların da alındığı çok daha geniş ve kapsayıcı bir hale dönüşmüştür. Hint konumlu sayı sistemini de barındıran cebir ve mukabele, matematiğin 9. yüzyılda sahip olduğu en yeni teknolojisi konumundadır. Bu yeni teknoloji (ilm-i hiyel eladediyye) sayesinde daha önce Antik Yunanlarca oran teorisine uymadığı için kabul görmeyen irrasyonel sayıların artık diğer sayılardan bir farkı kalmamıştır. Hem irrasyonel hem de rasyonel sayıların birbirlerine oranları sayıların birbirlerine oranları gibidir. 


\section{KAYNAKLAR}

Akalın, Atilla (2017). "Platon ve Sofistler'deTekhné ve Pathos Kavramları Üzerinden Bilgi, Hakikat ve Mugalata İlişkisi”, Uluslararası Medeniyet Calıșmaları Dergisi,C. 3, S. 1, s. 4-11.

Aristotle (2014). Physics, Translated in The Complete Works of Aristotle, Volume 1, The Revised Oxford Translation, editedby J.Barnes.

Aydın, Cengiz (1994). “Ebu Kâmil”, TDV İslam Ansiklopedisi, C. 10, s. 172-174. Aydoğan, Ahmet (2017). Heidegger: Teknoloji ve İnsanliğın Geleceği, Ankara: Say Yayınları.

Cajori,Florian (2014). Matematik Taribi, Çev. Deniz İlalan, Ankara: Odtü Yay. Cevizci, Ahmet (2014), İlkçă̆ Felsefesi, İstanbul: Say Yayınları.

Corry,Leo (2017). Sayıların Kısa Taribi, Çev. Özlem Kesici, Doruk Yayınları.

Dosay Gökdoğan,Melek ve Demir,Remzi (2019). “İslam ve Türk Uygarlığında Makine Tarihi”, Dört Öğe 14, s. 1-19.

Dosay, Melek (1991). Kerecînin “İlel Hesab el-Cebr ve’l-Mukâbele” Adlı Eseri, Ankara: AKM Yay.

Fazlığlu, İhsan ve Koç, Mustafa (2000). Tercüme-i Hiyel, İnceleme-Çeviri Yazı-Tıpkıbasım, İstanbul: Türkiye Yazma Eserler Kurumu Başkanlığı.

el-Hârezmi (2019). Mefâtihu'l-Ulûm, Çev. Aygün Akyol-İclâl Arslan, Ankara: Elis Yay.

Farabî (2019). İlimlerin Sayımı, Çev. Ahmet Arslan, İstanbul: İş Bankası Yay. Guenon, Rene (2012). Niceliğin Egemenliği ve Çağın Alametleri, Çev. Mahmut Kanık, İstanbul: İz Yayınc1lık.

Heidegger, Martin (2015). Teknik ve Dönüş E̊ Özdeşlik ve Ayrım, Çev. Necati Aça, Ankara: Pharmakon Yayınevi.

Hill, Donald R. (1991) "Arabic Mechanical Engineering: Survey of the Historical Sources”, Arabic Sciences and Philosphy, Vol. 1, p. 167-186.

İnam, Ahmet (2014). Teknoloji Benim Neyim Oluyor?, Ankara: Odtü Yayınları. Plato (2016). Laws, M. Schofield (ed.), T. Griffith (tr.), Cambridge: Cambridge University Press. 
Platon (2015). Timaios, Çev. Furkan Akderin, İstanbul: Say Yayınları.

Rosen, Frederic (1831). The Algebra of Mohammed ben Musa, London.

Say1l, Aydın (1996). Aydın Saynlinın Misırlılarda ve Mezopotamyalılarda Matematik, Astronomi ve Tip Adlı Eserinin Mubtasar, Yayına Haz. Mübahat Türker Küyel, Ankara: AKM Yay.

(2015). Orta Çă̆ Bilim ve Kültüründe Türklerin Yeri, Ankara: AKM Yay.

Ural, M. Nuri (2015). “Antik Yunan'da ‘Teknik': Teknoloji Felsefesi Üzerine Genel Bir Bakış”, Mavi Atlas 4/2015, s. 136-144. 